\title{
La procacidad de Ricardo Palma
}

GE sabe que Ricardo Palma renunció en 1912 a la dirección de la $D$ Biblioteca Nacional de Lima. En el mismo decreto en que aceptaba esa renuncia, el gobierno nombró como reemplazante a Manuel González Prada. En su deplorable Nota informativa acerca de la Biblioteca, Lima, 1912, González Prada acusó a Palma (pp. 15-22) de ensuciar los márgenes de los libros con "juicios no muy benévolos... falsedades... desfogues personales y hasta cacografías". Y para dar una idea, González Prada transcribe "algunas de las mil anotaciones", excusándose por la "incultura o grosería" de esas frases. Las apostillas son, nos asegura, de puño y letra de Palma. No lo negó Palma al contestar con sus Apuntes para la historia de la Biblioteca de Lima, Lima, 1912.

No reproduciremos esas indecencias. Sólo quisiéramos llamar la atención de los estudiosos sobre un aspecto de la creación artística de las Tradiciones peruanas. Por ejemplo, al margen de un alegato contra el virrey Amat por seducción de una mujer, Palma borronea un comentario obsceno. El carácter de ese Virrey pasa a muchas "tradiciones", pero Palma se limpia entonces la boca y habla sin procacidad: "licencioso en sus costumbres, escandalizó bastante al país con sus aventuras amorosas" es todo lo que se atreve a decir en "Rudamente, pulidamente, mañosamente". Pero la obscenidad seguía manando de Palma, en la conversación con los amigos, y fué a parar a un libro curiosísimo, del que pasamos a dar noticia.

En la biblioteca de Duke University (Durham, North Carolina), hemos leído unas traducciones inéditas de Ricardo Palma. Que sepamos, nadie las ha descrito. Tampoco figuran en las bibliografías corrientes. 
Es un volumen de cincuenta y una páginas dactilografiadas. Ni una palabra manuscrita, ni una firma.

En la cubierta: Tradiciones en salsa verde por Ricardo Palma. Lima, 1901.

En la primera página hay una nota: "Estas tradiciones están inéditas y han sido copiadas del manuscrito original de don Ricardo Palma, del cual no existe, según tengo entendido, más que un solo ejemplar; éste lo posee el señor Carlos E. Basadre". E1 anónimo autor de esta nota sólo indica lugar y fecha: Lima, 1905.

En la segunda página hay una dedicatoria a don Carlos Basadre: "Sabe usted, mi querido Carlos, que estas hojitas no están destinadas para la publicidad y que son muy pocos los que, en la intimidad de amigo a amigo, las conocen. Alguna vez me reveló usted el deseo de tener una copia de ellas y no sabiendo qué agasajo le sería grato hoy, día de su cumpleaños, le mando mis Tradiciones en salsa verde, confiando en que tendrá usted la discreción de no consentir que sean leídas por gente mojigata, que •se escandaliza no con las acciones malas sino con las palabras crudas. La moral no reside en la epidermis. Mil cordialidades. Su viejo amigo, El Tradicionalista. Lima. Febrero de 1904".

El índice: Nota (i) ; Dedicatoria (ii) ; Un desmemoriado (8) ; La consigna de Lara (11) ; Tajo o Tejo (14) ; El clavel disciplinado (16); Un calembourg (20); Otra improvisación del ciego de la Merced (23) ; La cosa de mujer (24); Fatuidad humana (27); De buena a bueno (31) ; Los inocentones (33) ; El lechero del convento (35) ; Pato con arroz (39) ; La moza del Gobierno (42) ; Matrícula de colegio (46); La cena del capitán (49); La misa a escape (51).

Palma, pues, preparó su manuscrito en 1901, lo regaló a Basadre en 1904 y alguien lo dactilografió en 1905. ¿Cómo llegó esta copia a Duke University? Mr. Thomas M. Simkins Jr., encargado de la sala de libros raros, nos informa que todo lo que se sabe es que fué comprada por la Universidad a Ferreyros, junto con una colección de manuscritos (Ferreyros' Peruvian Collection), el 16 de julio de 1929, a recomendación del profesor Rippy.

No dudamos que estas Tradiciones en salsa verde sean auténticas. La vis cómica, la estructura de cada relato $y$, sobre todo, la actitud ante la lengua son típicas de Palma. Que la fecha 1901 sea 
también auténtica no hay por qué dudarlo. En la primera tradición se dice: "Este parágrafo lo escribo para lectores del siglo $\mathrm{xx}$..."

Para esa fecha Palma había escrito las seis series de Tradiciones peruanas (1872-1883), a las que siguieron las de Ropa vieja (1889), Ropa apolillada (1891) y los dos tomitos titulados Cachivaches y Tradiciones y artículos históricos (1899-1900). Todavía escribirá más: en 1911 se está imprimiendo en Barcelona su Apéndice a mis últimas tradiciones. Pero es muy significativo que en 1900 Palma declarara: "He dicho adiós a la literatura". Las Tradiciones en salsa verde, pues, fueron escritas inmediatamente después de ese adiós. Qué le ocurrieron a sus tradiciones cuando Palma se despidió de la literatura es lo que quisiéramos comentar.

En muchas de sus Tradiciones peruanas había bordeado Palma lo picaresco, pero sin caer en la pornografía. Aun la salacidad del pueblo solía evaporarla en nubes literarias. Ahora, al renunciar a la literatura, el arroyo queda arroyo; y el anciano se hunde en la pornografía como un niño que chapalea en el fango. Ninguna de las Tradiciones en salsa verde es artísticamente valiosa. Aun las mejores - "La cena del capitán", "Fatuidad humana"— son más bien chistes verdes. Otras repugnan por la grosería sexual, como "Matrícula de colegio" o "La consigna de Lara". La mayoría de ellas están construídas sobre meros juegos de palabrotas o con viles anécdotas. Sus héroes son de monstruosa anatomía: sólo existen de la cintura para abajo. Su fisiología no es más complicada que la del perro.

Es posible que, de oirlas contar al mismo Palma o a otro buen conversador, saludáramos a carcajadas cualquiera de estas tradiciones. Leídas, disgustan. ¿En qué consiste este no poder triunfar a la vez, con la misma vena soez, en la literatura y en la conversación? Tal vez una sociología de los sentidos de la vista y del oído nos aclarara el conflicto entre lengua escrita y lengua oral, entre el cuento sucio que Boccaccio escribe en el Decamerone y el cuento inmundo que el mismo Boccaccio debió de decir y no se atrevió a escribir. Porque siempre ha habido excelentes especímenes de literatura sucia. Pero cuando la suciedad ha llegado a esa altura de excelencia es porque ya era normal que las bocas de todo el mundo la llevara. La literatura es relativamente pudorosa. Nos invita a ingresar en una sociedad responsable, abierta, pública, permanente, seria. Es incompatible, pues, con el cuento obsceno, que nace de 
una actitud antisocial y circula en un grupo que se reúné ocasionalmente. Desde el café, la plaza, el camarote, la esquina, el velatorio o el mingitorio unos habladores disparan agresivos sonidos contra las normas del buen gusto. Para ellos la mala palabra, la mala intención son esenciales. Las exhiben desnudas porque en su desnudez está la gracia. Todo el interés del auditorio se desborda hacia la anhelada indecencia. Mencionarla u oirla mencionada es una liberación de represiones morales, un desafío al tabú, una descarga de malicias, una creación, a veces poética, en el medio vivo e inmediato del acento, la mirada y la mímica. Así, el cuento verde liga a los hombres íntimamente, como en una masonería secreta. Al pan, pan $\mathrm{y}$ al vino, vino. Andar con vueltas sería sobresaltar al grupo con la sospecha de que uno de los miembros no merece la confianza, de que un espía o un testigo desleal se ha deslizado en la reunión. Cada asociado tiene que probar su solidaridad con el chiste festejándolo a risotadas, a palmadas sobre el muslo, a gritos de " $i$ muy bueno, muy bueno, che!" $O$, más delicadamente, superándolo con otro. Son cómplices y, a pesar de sus indiscreciones para con las bajezas humanas, ejercitan la virtud de la discreción para guardar sus chistes en la esfera de la voz. Si alguien ajeno al rito escatológico y sicalíptico irrumpiera de pronto, callarían todos, desviarían la conversación, a menos que tuvieran buenas razones para incorporar al recién llegado. Es la discreción característica de las camarillas clandestinas. La asociación secreta de los druidas de las Galias prohibía que se escribieran sus cantos: cada druida debía aprenderlos de memoria y transmitirlos oralmente. Del mismo modo los chistosos de la pornografía no fijan por escrito su repertorio: lo enriquecen en una jerga oral. Se sienten más hombres si el trato personal es la única fuente del aprendizaje.

Ricardo Palma cometió una traición a esos hombres : la traición de pasarse de un género oral a otro escrito y de revelar el secreto de un culto. La inmoralidad de esta traición, no la inmoralidad de contar los pelos y señales del sexo, es lo que choca en sus Tradiciones en salsa verde.

Enrique Anderson Imbert, Ann Arbor, Michigan. 